\title{
Economic Growth, Energy Intensity, and Carbon Dioxide Emissions in China
}

\author{
Eric Yaw Naminse ${ }^{1,2 *}$, Jincai Zhuang ${ }^{1}$ \\ ${ }^{1}$ School of Management, Jiangsu University, Zhenjiang, P.R. China \\ ${ }^{2}$ School of Economics and Management, Qinzhou University, Guangxi, P.R. China
}

Received: 19 September 2017

Accepted: 14 October 2017

\begin{abstract}
With China's rapid economic growth over the past three decades, the emission of greenhouse gases (GHG) has become more serious to the environment, with debilitating effects on both flora and fauna. This paper mainly investigates the relationship among economic growth, energy intensity, and $\mathrm{CO}_{2}$ emission in China using static and dynamic regressions, Granger causality, and impulse response function.

The results show that by comparing the values of different energy intensities, coal consumption is the highest with mean value of 4.296, which is followed by oil (0.817), electricity (0.226), and gas (0.098). Thus, China's heavy reliance on coal consumption is possibly a dominant cause for the increase in carbon dioxide emissions. The results also indicate that $\mathrm{CO}_{2}$ emissions have an inverted U-shaped link with per capita income, and this supports the existence of the environmental Kuznets curve (EKC) hypothesis in China. Furthermore, economic growth has a bidirectional relationship with coal energy consumption, while coal consumption also has a bidirectional link with $\mathrm{CO}_{2}$ emissions. Based on the findings, we suggest that environmental technologies should be improved through efficiency-enhancing strategies to reduce $\mathrm{CO}_{2}$ emissions.

Finally, China's Ministry of Environmental Protection should strictly enforce existing laws and regulations on the environment, and also encourage a shift from the use of fossil fuels to clean energy sources such as ethanol gas, as well as promote the use of eco-friendly vehicles such as electric cars and motors.
\end{abstract}

Keywords: $\mathrm{CO}_{2}$ emissions, energy intensity, growth, China

\section{Introduction}

With high economic development activities, more greenhouse gases (GHG) are being emitted, which cause global warming with negative consequences on crop vegetation and environmental sustainability

*e-mail: yawric@yahoo.com
[1-2]. According to the U.S. National Aeronautics and Space Administration (NASA) Goddard Institute for Space Studies (GISS), global land-ocean temperatures have increased greatly from the year 1880 to 2000 , and it is projected to even further increase by 2020 . In Fig. 1, below, we observe that there has been a decline in temperatures from 1880 to 1910 , then a sharp increase from 1910 to 1940. There was a fall from 1940 to 1950 , and then a rapid increase again from 1950 to 2000 and beyond. It is estimated that energy consumption is likely 


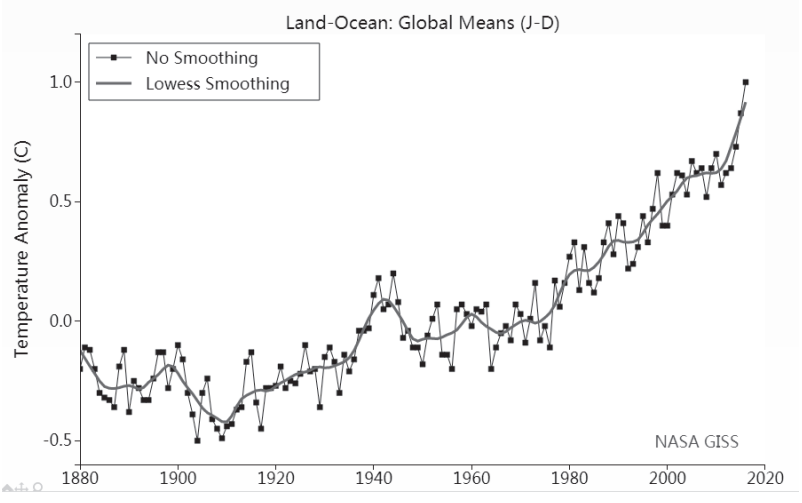

Fig. 1. Global trend in land-ocean temperatures [3].

to be a dominant cause of carbon dioxide emissions especially for nonrenewable energy consumption, which has affected global warming in recent years.

China continues to be the largest $\mathrm{CO}_{2}$-emitting country in the world based on its share of global $\mathrm{CO}_{2}$ emissions (Fig. 2). To some extent, this is anticipated since the country is still in the phase of industrialization. Some pollution-intensive industries such as iron and steel, cement, paper, and pulp depend heavily on energy investments, which have led to severe environmental pollution.

Fig. 3 shows that $\mathrm{CO}_{2}$ emissions in China have increased greatly with the development of the economy over the years. Prior to the 1978 rural economic reforms, both GDP and $\mathrm{CO}_{2}$ emissions had static growth, and afterward $\mathrm{CO}_{2}$ emissions increased steadily alongside economic development.

We also find that carbon dioxide emissions have increased rapidly with coal consumption. Most electricity, cement production, and some economic activities are generated by coal in China, which emits a great deal of $\mathrm{CO}_{2}$ into the environment. Hence, it would be necessary to control the energy consumption structure in China in order to reduce total energy use by expanding renewable energy consumption opportunities. In this way, carbon dioxide emissions may be reduced, and the environment protected from further depletion.

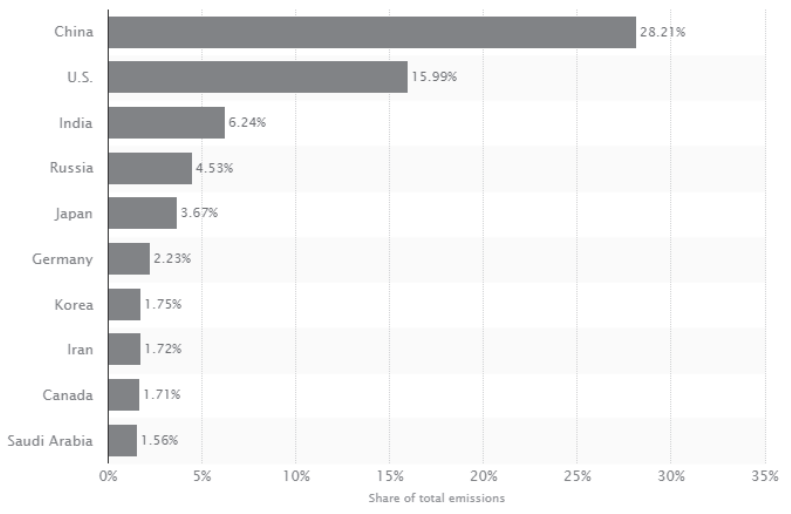

Fig. 2. Global $\mathrm{CO}_{2}$ emissions in 2016 [4].

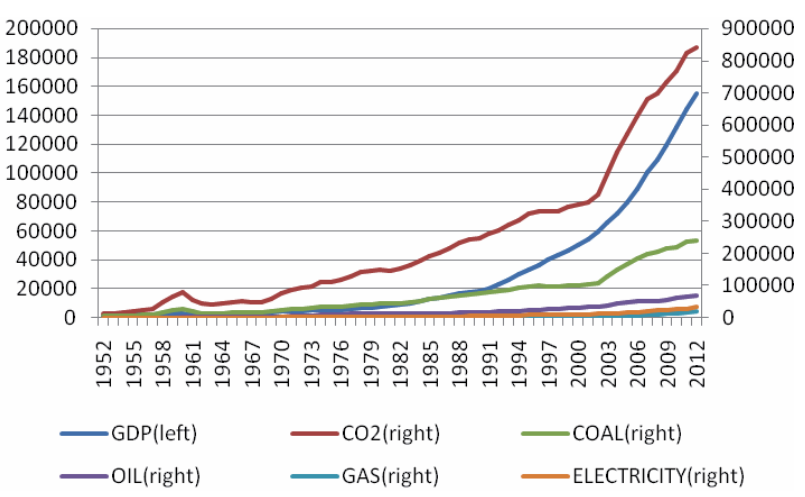

Fig. 3. Trends in GDP, $\mathrm{CO}_{2}$ emissions, and energy consumption in China.

This paper, therefore, investigates the relationship among economic growth, energy intensity, and carbon dioxide emissions in China using static and dynamic analyses. The rest of the paper is organized in the following manner: we examine the background and some applications of the environmental Kuznets curve (EKC) hypothesis for studies in different countries. This is followed by material and methods including the econometric model and data. The results and discussion follow suit and, finally, conclusions and policy recommendations.

\section{Background on Environmental Kuznets Curve Hypothesis}

With the development of industrialization, environmental pollution has become more serious. Many scholars have investigated the relationship among energy consumption, environmental pollution, and economic growth. The EKC hypothesis put forward states that there is an inverted $U$ shape in the long-term relationship between environmental degradation and economic growth in most economies [5]. The EKC theory is actually an extension of the original Kuznets' inverse U-shaped relationship found between inequality and per capita income in the United States [6]. After the birth of EKC, the theory aroused great interest amongst scholars from different countries. The results from previous research based on EKC mostly confirm its existence in many countries - especially in Asia and Africa [7-13]. Other studies that examined the EKC hypothesis include a study to examine the consequences of corrupt and rent-seeking attitude by government to determine the relationship between pollution and economic growth. They found that corruption is unlikely to preclude an inverted U-shaped relationship under cooperative and non-cooperative interactions between government and private firms, while pollution levels and corrupt attitudes correspond to each other [14].

Using data from the International Energy Agency (IEA) made up of OECD and non-OECD nations to examine the robustness of EKC for $\mathrm{CO}_{2}$, the research 
found that $\mathrm{EKC}$ is not dependent on data source; although an inverted U-shaped relationship exists in OECD nations, but not in non-OECD nations [15].

As to whether there is an animal welfare Kuznets curve using animal concerns in agriculture, laboratories, pets, and the fur industry, another study found mixed results, with measures not showing signs of improved animal welfare [16]. A study on the causal relationship between per capita GDP and solid waste generation in Henan Province, China, confirmed the EKC hypothesis existence between them [17].

In Suzhou, a city in China, the EKC principle was used to examine the relationship among waste disposal, economic growth, and trade growth. It was realized that as GDP value and export volumes increase, waste disposal also increased significantly [18]. The relationship among real GDP, $\mathrm{CO}_{2}$ emissions, and energy consumption using data from 12 Middle East and North African (MENA) countries from 1981 to 2005 found that GDP has a quadratic relationship with $\mathrm{CO}_{2}$ emissions, while energy consumption positively impacts carbon dioxide emissions [19]. In the long-run, income and carbon emissions satisfy the EKC conditions but with non-uniform points of inflexion, which imply weak support for the EKC inverted U-shaped hypothesis.

An estimated long- and short-run elasticity of energy consumption and energy $R \& D$ to variations in oil prices and income for 20 OECD (Organization for Economic Co-operation and Development) member countries from 1980 to 2010 using NPAM (Nerlove partial adjustment model) for the analysis found that economic growth led to an increase in the use of cleaner energy forms, thereby promoting R\&D in renewable energy [20].

A study on the nexus between economic growth and biomass consumption for 51 nations in sub-Saharan Africa also found that economic growth significantly impacts biomass consumption [21]. In terms of coal consumption and economic growth, there exists a bidirectional relationship between them in Pakistan [22], when error correction model (ECM) and Granger causality tests were employed on data from 1974 to 2010.

Last but not the least, using monthly data from 1981 to 2014, a recent study [23] based on Pearson's Correlation method shows that vegetation dynamics are significantly affected by changes in climatic factors in northeastern China.

The following are the potential innovativeness of the paper: first we analyzed the relationship among economic growth, energy intensity, and carbon dioxide emissions in China using static and dynamic regression methods. Second, we compared the static and dynamic effects of economic growth and energy intensity on carbon dioxide emissions. Third, we employed Granger causality to examine the likely mutual impacts, and also used the impulse response function to analyze the future possible influence of energy intensities on carbon dioxide emissions.

\section{Material and Methods}

\section{Econometric Model and Data Source}

This paper mainly investigates the relationship among economic growth, energy intensity, and carbon emissions in China. We also check for the existence of EKC hypothesis in China through time series data analysis from 1952 to 2012. Following EKC (Grossman and Krueger, 1994), the econometric model is stated as in Equation (1):

$$
\begin{aligned}
\mathrm{CO}_{2 \mathrm{t}} & \left.=\alpha+\beta_{1} \text { income }_{\mathrm{t}}+\beta_{2} \text { (income }_{\mathrm{t}}\right)^{2}+\beta_{3} \text { industry }_{\mathrm{t}} \\
& +\beta_{4} \text { coal }_{\mathrm{t}}+\beta_{5} \text { oil }_{\mathrm{t}}+\beta_{6} \text { gas }_{\mathrm{t}}+\beta_{7} \text { elec }_{\mathrm{t}}+\varepsilon_{\mathrm{t}}
\end{aligned}
$$

...where $\mathrm{CO}_{2 \mathrm{t}}$ is carbon dioxide emission in metric tons per capita, as the dependent variable; while income, income $^{2}$, industry, coal, oil, gas, and elec are the real income per capita, square of real income per capita, industry, and coal, oil, gas and electricity consumption per capita, are the independent variables with $\varepsilon$ denoting the random disturbance, $\alpha$ is the constant variance and $\beta_{1}$ to $\beta_{7}$ are coefficients of variation. To lessen heterogeneity of different units, we take logarithm for the related variables.

The static model is indicated as in Equation (2):

$$
\begin{gathered}
\left.\ln \mathrm{CO}_{2 \mathrm{t}}=\alpha+\beta_{1} \text { Inincome }_{\mathrm{t}}+\beta_{2} \text { (Inincome }_{\mathrm{t}}\right)^{2} \\
+\beta_{3}+\text { lnindustry }_{\mathrm{t}}+\beta_{4} \ln \text { coal }_{\mathrm{t}}+\beta_{5} \operatorname{lnoil}_{\mathrm{t}} \\
+\beta_{6} \operatorname{lngas}_{\mathrm{t}}+\beta_{7} \ln _{\text {nelec }}+\varepsilon_{\mathrm{t}}
\end{gathered}
$$

...where $\ln \mathrm{CO}_{2}$, Inincome, lnincome ${ }^{2}$, lnindustry, Incoal, Inoil, Ingas, and $\ln$ elec are the natural logs of $\mathrm{CO}_{2}$ emissions (metric tons) per capita, real income per capita, square of real income per capita, industry, and coal, oil, gas and electricity consumption per capita, and $\varepsilon$ denotes the random disturbance, $\alpha$ is the constant variance, and $\beta_{1}$ to $\beta_{7}$ are coefficients of variation. The square of income is added in order to test the EKC. We compute industry rate through the ratio between industry and GDP, both of which have been deflated according to the base year of 1990 .

Energy intensity is defined as the use of energy over GDP or energy input over industrial output [24-28], and thus:

$$
\mathrm{EI}=\mathrm{e} / \mathrm{y}=\mathrm{EC} / \mathrm{GDP}
$$

...where EI is energy intensity, e is energy consumption (EC), and y is gross domestic product (GDP).

Equations (1-3) estimate different energy intensities through the ratio of coal, oil, gas, electricity consumption, and GDP. We used annual time series data taken from 1952 to 2012, which is obtained from China's Compendium of Statistics (1949-2008) and the Statistical Yearbook. 
In order to take care of dynamic changing effect, we also differentiate all variables on both sides of the static equation. The dynamic model is indicated in Equation (4) as:

$$
\begin{gathered}
\Delta \ln \mathrm{CO}_{2 \mathrm{t}}=\alpha+\beta_{1} \Delta \text { lnincome } \\
\text { th }_{\mathrm{t}}+\beta_{2} \Delta \\
\left(\text { Inincome }_{\mathrm{t}}\right)^{2}+\beta_{3} \Delta \text { industry }_{\mathrm{t}}+\beta_{4} \Delta \ln \text { coal }_{\mathrm{t}} \\
+\beta_{5} \Delta \text { lnoil } \mathrm{t}_{\mathrm{t}}+\Delta \text { lngas }_{\mathrm{t}}+\beta_{7} \Delta \text { ln }_{4} \text { elec }_{\mathrm{t}}+\varepsilon_{\mathrm{t}}
\end{gathered}
$$

...where $\Delta l n \mathrm{CO}_{2}, \Delta l$ nincome, $\Delta l$ lnincome ${ }^{2}, \Delta l$ nindustry, $\Delta$ lncoal, $\Delta$ lnoil, $\Delta$ lngas, and $\Delta$ lnelec indicate the differentiation of the natural logs of $\mathrm{CO}_{2}$ emission (metric tons) per capita, real income per capita, square of real income per capita, industry, and coal, oil, gas and electricity consumption per capita; $\varepsilon$ is the random disturbance; $\alpha$ is the constant variance; and $\beta_{1}$ to $\beta_{7}$ are coefficients of variation.

Other studies found that $\mathrm{CO}_{2}$ emissions have increased with industrial development in China. Industries have contributed largely to China's economic growth, especially in heavy industries. On the other hand, these heavy industries have seriously polluted the natural environment of China, requiring stakeholders to develop environmentally friendly technologies to reduce pollution.

\section{Results and Discussion}

We first conduct descriptive analysis, and then test EKC in China by static and dynamic regressions. Then, Granger causality analysis is conducted to analyze the mutual relationships among energy intensity, economic growth and carbon dioxide emissions. We also employ the impulse response function to predict how different energy intensities might influence carbon dioxide emissions in the next 30 years.

\section{Descriptive Analysis}

According to Table 1, the mean of $\mathrm{CO}_{2}$ is $238,908.4$. It can be observed that $\mathrm{CO}_{2}$ emission has the greatest standard deviation of 224,766.9, which is followed by income at 2,894.771.
By comparing the values of different energy intensities, coal is higher than the other forms of energy used with a mean value of 4.296986. This implies that China continues to use more coal than any other source of energy, which is a dominant possible cause of carbon dioxide emissions in the country. This is in line with recent findings on the relationship between coal consumption and economic growth in China [29], and Chen [30] also found that coal consumption in China mainly consists of soft coal of about $75-80 \%$ and anthracite coal of about $20 \%$.

\section{Static Analysis}

We conduct static regression analysis to determine the effects of real income per capita, square of real income per capita, industry, and coal, oil, gas and electricity consumption per capita as well as economic growth (GDP) on carbon dioxide emissions. Table 2 shows the results on the determinants of carbon dioxide emissions. It indicates that $\mathrm{CO}_{2}$ emissions have an inverted U-shaped relationship with income, which conforms to the EKC hypothesis. Accordingly, as income increases in China, the emission of carbon dioxide also increases. It appears then, that economic development is dependent on environmental pollution in the early phase of industrialization. When environmental pollution worsens, government tends to strengthen environmental regulations thereafter.

The results also show that carbon dioxide emissions will decrease with an increase in per capita income, while industry rate has a positive influence on carbon dioxide emissions. Furthermore, the signs of industry rate are positive, even though it is statistically insignificant in models III (0.0618) and IV (0.0563). Also, the values of $\mathrm{R}^{2}$ in all the models are above $90 \%$, and this indicates the relatively high explanatory power of the independent variables on the dependent variable.

We can observe that industries such as cement, paper, iron, and steel firms have contributed largely to polluting the natural environment of China. Nowadays, pollution-intensive industries have caused great hazards in many cities in China. It is better to develop clean industries to control environmental

Table 1. Descriptive analysis results.

\begin{tabular}{|c|c|c|c|c|c|}
\hline Variable & Unit & Mean & Std.Dev. & Min & Max \\
\hline $\mathrm{CO}_{2}$ & 10,000 ton & $238,908.4$ & $224,766.9$ & $13,509.53$ & $842,402.2$ \\
\hline Income & Yuan & $2,359.205$ & $2,894.771$ & 247.102 & $11,498.01$ \\
\hline Industry & $\%$ & 0.348 & 0.136 & 0.095 & 0.559 \\
\hline Coal & 10,000 ton coal equivalent/ 100 mil.Yuan & 4.297 & 1.932 & 1.552 & 9.854 \\
\hline Oil & 10,000 ton coal equivalent/ 100 mil.Yuan & 0.817 & 0.481 & 0.127 & 1.995 \\
\hline Gas & 10,000 ton coal equivalent/ 100 mil.Yuan & 0.098 & 0.07 & 0.002 & 0.276 \\
\hline Electricity & 10,000 ton coal equivalent/ 100 mil.Yuan & 0.226 & 0.077 & 0.061 & 0.373 \\
\hline
\end{tabular}


Table 2. Static analysis results.

\begin{tabular}{|c|c|c|c|c|}
\hline \multirow{2}{*}{ Variables } & \multicolumn{4}{|c|}{ Dependent variable: $\ln \mathrm{CO}_{2}$} \\
\hline & Model I & Model II & Model III & Model IV \\
\hline \multirow{2}{*}{ lnincome } & 1.123 & 0.442 & $1.398 * * *$ & $1.396 * * *$ \\
\hline & $(0.677)$ & $(0.6)$ & $(0.118)$ & $(0.119)$ \\
\hline \multirow{2}{*}{$(\text { Inincome })^{2}$} & $-0.0756^{* *}$ & -0.0429 & $-0.0242 * * *$ & $-0.0241 * * *$ \\
\hline & $(0.037)$ & $(0.0326)$ & $(0.00576)$ & $(0.00581)$ \\
\hline \multirow{2}{*}{ industryrate } & & $5.502 * * *$ & 0.0618 & 0.0563 \\
\hline & & (1.197) & $(0.177)$ & $(0.181)$ \\
\hline \multirow{2}{*}{$\operatorname{lncoalGDP}$} & & & $0.884 * * *$ & $0.885 * * *$ \\
\hline & & & $(0.028)$ & $(0.0283)$ \\
\hline \multirow{2}{*}{ InoilGDP } & & & $0.192 * * *$ & $0.193 * * *$ \\
\hline & & & $(0.0199)$ & $(0.0204)$ \\
\hline \multirow{2}{*}{ lngasGDP } & & & $-0.0279 * *$ & $-0.0270 *$ \\
\hline & & & $(0.0139)$ & $(0.0149)$ \\
\hline \multirow{2}{*}{ InelecGDP } & & & & -0.00463 \\
\hline & & & & $(0.0252)$ \\
\hline \multirow{2}{*}{ Year } & $0.0593 * * *$ & $0.0307 * * *$ & $0.0117 * * *$ & $0.0119 * * *$ \\
\hline & $(0.0112)$ & $(0.0115)$ & $(0.00311)$ & $(0.00323)$ \\
\hline \multirow{2}{*}{ Constant } & $-109.7 * * *$ & $-51.87 * *$ & $-21.25 * * *$ & $-21.51 * * *$ \\
\hline & (19.64) & $(21.06)$ & $(5.739)$ & $(5.956)$ \\
\hline Obs. & 61 & 61 & 61 & 61 \\
\hline $\mathrm{R}^{2}$ & 0.964 & 0.974 & 0.9997 & 0.9997 \\
\hline
\end{tabular}

Note: Standard deviations are in parentheses. Statistically significant at $1 \%(* * *), 5 \%(* *)$, and $10 \%(*)$ levels.

pollution. Compared with other energy uses, coal energy intensity has the largest influence on carbon dioxide emissions. Oil intensity has a positive impact on environmental pollution. It is found that gas intensity has a negative impact on carbon dioxide emissions. Even though electricity intensity is insignificant, the sign of its influencing coefficient is negative. It is better to change energy structure in China to control the consumption of fissile energy. It is advisable to explore and use more nonrenewable energy as a way to protect the environment. With time, environmental pollution has become more severe in the country and it is important to develop value-added products of coal, such as coal coking, electricity generated by coal, and coal gasification in order to decrease carbon dioxide emissions.

\section{Dynamic Analysis}

Following static regression, we also employ the dynamic regression analysis method to examine the determinants of carbon dioxide emissions. The results of the dynamic analysis as shown in Table 3 are almost similar to those of the static results. Carbon dioxide emissions changes have inverted U-shaped links with per capita income changes. For instance, the sign of income is positive while the sign of change in income is negative in all models, and they are all statistically significant.

The differentiation of industry rate has a positive impact on the carbon dioxide emission changes. It is important to transform industry structure to develop green innovation to decrease environmental pollution. Also, the changes of coal intensity have the largest influence on carbon dioxide emission changes.

The oil intensity changes have a positive impact on carbon dioxide emissions changes. This implies that it is important to decrease fossil energy and rather explore the diversification of their value-added products. It is also found that change in gas intensity has a negative influence on carbon dioxide emissions.

\section{Granger Causality Analysis}

This method is employed in the study as a statistical null hypothesis tool due to its suitability for detailed 
Table 3. Dynamic analysis results.

\begin{tabular}{|c|c|c|c|c|}
\hline \multirow{2}{*}{ Variables } & \multicolumn{4}{|c|}{ Dependent variable: D. $\ln \mathrm{CO}_{2}$} \\
\hline & Model I & Model II & Model III & Model IV \\
\hline \multirow{2}{*}{ D.lnincome } & $3.502 * * *$ & $1.776^{* *}$ & $1.316^{* * *}$ & $1.316^{* * *}$ \\
\hline & $(0.78)$ & $(0.796)$ & $(0.0835)$ & $(0.0843)$ \\
\hline \multirow{2}{*}{ D.lnincome2 } & $-0.185^{* * *}$ & $-0.103^{*}$ & $-0.0222 * * *$ & $-0.0221 * * *$ \\
\hline & $(0.0593)$ & $(0.0554)$ & $(0.00595)$ & $(0.00604)$ \\
\hline \multirow{2}{*}{ D.industryrate } & & $4.985 * * *$ & 0.13 & 0.129 \\
\hline & & $(1.174)$ & $(0.14)$ & $(0.141)$ \\
\hline \multirow{2}{*}{ D. $\operatorname{lncoalGDP}$} & & & $0.902 * * *$ & $0.902 * * *$ \\
\hline & & & $(0.0157)$ & $(0.0159)$ \\
\hline \multirow{2}{*}{ D.lnoilGDP } & & & $0.135 * * *$ & $0.135 * * *$ \\
\hline & & & $(0.0171)$ & $(0.0175)$ \\
\hline \multirow{2}{*}{ D.lngasGDP } & & & $-0.0113 * *$ & $-0.0119 *$ \\
\hline & & & $(0.0054)$ & $(0.00619)$ \\
\hline \multirow{2}{*}{ D.lnelecGDP } & & & & 0.00193 \\
\hline & & & & $(0.01)$ \\
\hline \multirow{2}{*}{ Constant } & 0.0205 & 0.0148 & $0.0145 * * *$ & $0.0144 * * *$ \\
\hline & 0.0174 & 0.0153 & 0.00199 & 0.00209 \\
\hline Observation & 60 & 60 & 60 & 60 \\
\hline $\mathrm{R}^{2}$ & 0.496 & 0.619 & 0.997 & 0.997 \\
\hline
\end{tabular}

Note: Standard deviations are in the parentheses. Statistically significant at $1 \%(* * *), 5 \%(* *)$, and $10 \%(*)$ levels.

analysis of time-series data. The Granger causality method not only helps to indicate the dimensions of the impact or effect between two variables, but enables the dynamic relationship between two pairs of variables to be specified. In other words, the Granger causality method is used to determine whether two different variables have a mutual relationship or otherwise. According to Soytas [31], the results of applying the Granger causality method offers more convincing evidence for policy decision-making process. Results of Granger causality method can be one-way (unidirectional), two-way (bidirectional), or no mutual (neutral) relationship [32].

Therefore, the Granger causality analysis method is employed in this study to mainly test whether different energy consumption and $\mathrm{CO}_{2}$ emissions have a two-way relationship or not.

As evidenced by Table 4, coal consumption has a two-way Granger causal relationship with carbon dioxide emissions in China. As a nonrenewable energy source, the use of coal in China needs to be reconsidered if environmental pollution is to be drastically reduced. From the table below, oil consumption and carbon dioxide emissions, however, have no mutual relationship, while the link between gas usage and $\mathrm{CO}_{2}$ emissions has a unidirectional relationship. It therefore appears that some part of income is derived from the causes of environmental pollution in China.

\section{Impulse Response Function Analysis}

Impulse response analysis has also been employed to predict four different energy intensities' influence on carbon dioxide emissions for the next 30 years in China (see Fig. 4). This indicates that coal consumption has the greatest impact on carbon dioxide emissions, which in turn means that $\mathrm{CO}_{2}$ emissions will continue to increase before the forward $4^{\text {th }}$ year and decrease from the coming 4th to the 6th years, after which it will have a positive response with the consumption of coal again until the 10th year, and then decrease slightly, but rises again into the $30^{\text {th }}$ year.

The least effect of the four different energy intensity scenarios on $\mathrm{CO}_{2}$ emissions is gas. It has a negative response to $\mathrm{CO}_{2}$ emissions from the forward $5^{\text {th }}$ year by dropping steeply and continues in the negative region for the coming 25 years. It is against this backdrop that China is encouraged to explore more use of gas, followed by biofuel and finally electricity generated from renewable sources, instead of the continuous heavy reliance on coal consumption with its negative impact on the environment. 
Table 4. Granger causality analysis results.

\begin{tabular}{|c|c|c|c|}
\hline Null Hypothesis: & Observation & F-Statistic & Probability** \\
\hline COALG does not Granger Cause $\ln \mathrm{CO}_{2}$ & 59 & 10.7491 & 0.00012 \\
\hline $\ln \mathrm{CO}_{2}$ does not Granger Cause COALG & 59 & 9.01519 & 0.00042 \\
\hline OILG does not Granger Cause $\ln \mathrm{CO}_{2}$ & 59 & 0.39186 & 0.67771 \\
\hline $\ln \mathrm{CO}_{2}$ does not Granger Cause OILG & 59 & 1.07764 & 0.34760 \\
\hline GASG does not Granger Cause $\ln \mathrm{CO}_{2}$ & 59 & 1.53155 & 0.22544 \\
\hline $\ln \mathrm{CO}_{2}$ does not Granger Cause GASG & 59 & 5.90269 & 0.00480 \\
\hline ELECG does not Granger Cause $\ln \mathrm{CO}_{2}$ & 59 & 1.08718 & 0.34443 \\
\hline $\ln \mathrm{CO}_{2}$ does not Granger Cause ELECG & 59 & 0.92207 & 0.40386 \\
\hline THIRDRATE does not Granger Cause $\ln \mathrm{CO}_{2}$ & 59 & 0.04689 & 0.95423 \\
\hline $\ln \mathrm{CO}_{2}$ does not Granger Cause THIRDRATE & 59 & 5.53485 & 0.00651 \\
\hline $\ln \mathrm{INCOME}$ does not Granger Cause $\ln \mathrm{CO}_{2}$ & 59 & 3.95183 & 0.02502 \\
\hline $\ln \mathrm{CO}_{2}$ does not Granger Cause $\ln \mathrm{INCOME}$ & 59 & 3.13043 & 0.05172 \\
\hline $\ln \mathrm{CO}_{2}$ does not Granger Cause $\ln$ INDUSTRY & 59 & 2.29528 & 0.1105 \\
\hline $\ln \mathrm{INDUSTRY}$ does not Granger Cause $\ln \mathrm{CO}_{2}$ & 59 & 4.72905 & 0.0128 \\
\hline
\end{tabular}

Note: statistically significant at $1 \%(* * *), 5 \%(* *)$, and $10 \%(*)$ levels

\section{Conclusions and Policy Recommendations}

As a result of the rapid economic growth in China, there has been an accompanying dramatic increase in carbon dioxide emissions over the years. In this study, therefore, we investigated the relationships among economic growth, energy intensity, and carbon dioxide emissions in China using static and dynamic analyses.

1) The results show that coal consumption is the dominant form of energy in China with a mean value of 4.296 as compared to oil, electricity, and gas, with mean values of $0.817,0.226$, and 0.098 , respectively.

Response to One S.D. Innovations

Response of $\mathrm{LN} \mathrm{CO}$ to COALG

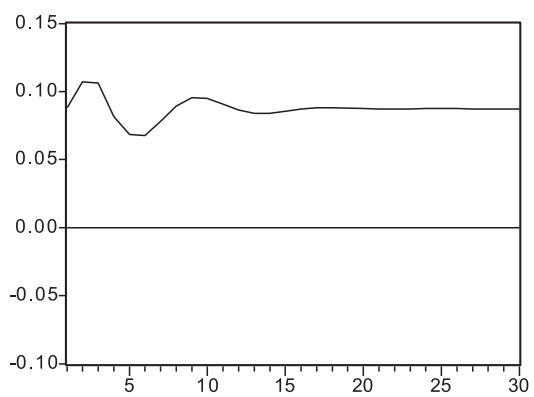

Response of $\mathrm{LN} \mathrm{CO}$ to GASG

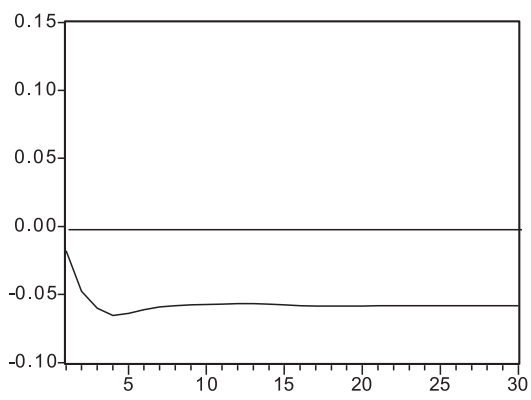

Response of $\mathrm{LN} \mathrm{CO}$ to ELEG

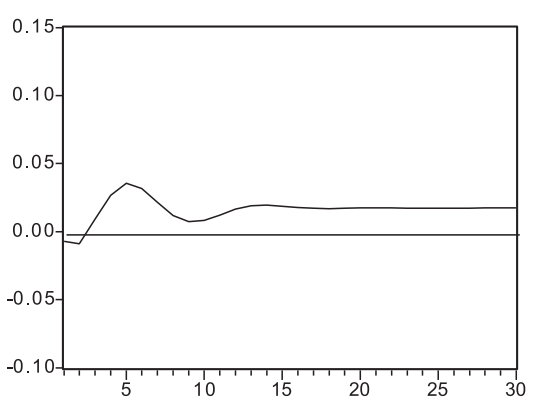

Response of $\mathrm{LN} \mathrm{CO}$ to OILG

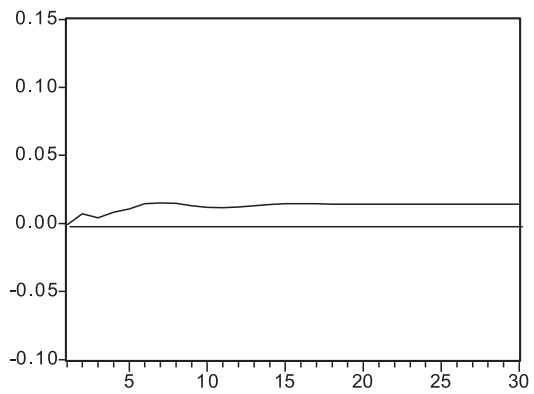

Fig. 4. Impulse response function analysis results. 
2) The results also indicate that there is an inverted U-shaped link between carbon dioxide emissions and income, which is a confirmation of the existence of the EKC hypothesis in China.

3) We further employ the Granger causality analysis, which shows that coal consumption has a bidirectional link with carbon dioxide emissions, while oil consumption and $\mathrm{CO}_{2}$ emissions have a neutral relationship.

4) Furthermore, gas consumption has a unidirectional causal relationship with carbon dioxide emissions, which means that ...

5) With impulse response function analysis, this study indicates that coal, electricity, and oil consumption have significant positive effects on carbon dioxide emissions, while gas consumption has the least and negative impact on $\mathrm{CO}_{2}$ emissions based on forecasts for the next 30 years using 4 different energy intensities.

Overall, the unprecedented economic growth of China has resulted in great use of energy, leading to an increase in $\mathrm{CO}_{2}$ emissions. Policywise, we recommend that in order to ensure sustainable economic growth with less damage to the environment:

1) Major industries in China with high pollution tendencies should be encouraged to improve technologies to limit carbon dioxide emissions through strict enforcement of the country's environmental laws. For instance, heavy fines should be imposed on the 'dirtiest' industries to deter others.

2) The Ministry of Environment and Protection should educate industry managers on the need and methods to improve efficiency in energy use through new technologies that will help protect the natural environment of China.

3) Finally, we suggest that policymakers should encourage coal gasification in China, which can offer better environmental benefits at lower cost in helping address the concerns on the atmospheric buildup of greenhouse gases such as carbon dioxide.

These measures, among others when fully implemented, can help promote sustainable economic growth and development in China, without much destruction to the natural environment.

\section{Acknowledgements}

This work was funded by the National Natural Science Foundation of China (NSFC) with grant No. 71473106 , and we appreciate the support. The authors are also grateful to the anonymous reviewer and the editor for their insightful comments and suggestions, which have helped to improve the paper.

\section{References}

1. HUSSAIN S., PENG S., FAHAD S., KHALIQ A., HUANG J., CUI K., NIE L. Rice management interventions to mitigate greenhouse gas emissions: a review. Environmental Science and Pollution Research, 22, 3342, 2014.

2. BRAVO G., LÓPEZ D., VÁSQUEZ M., IRIARTE A. Carbon Footprint Assessment of Sweet Cherry Production: Hotspots and Improvement Options. Polish Journal of Environmental Studies, 26, 563, 2017.

3. Global trend in land-ocean temperatures. https://data.giss. nasa.gov/gistemp/graphs/customize.html. Date accessed: June 1, 2017.

4. Largest producers of carbon dioxide emission worldwide in 2016. https://www.statista.com/statistics/271748. Date accessed: June 3, 2017.

5. GROSSMAN G.M., KRUEGER A.B. Economic growth and the Environment. National Bureau of Economic Research (NBER) Working Paper, No. 3914. Cambridge, MA, 27, 1994.

6. KUZNETS S. Economic growth and income inequality. American Economic Review, 45, 24, 1955.

7. ANG J.B. $\mathrm{CO}_{2}$ emissions, energy consumption, and output in France. Energy Policy, 35, 4776, 2007.

8. JALIL A., MAHMUD S. F. Environment Kuznets curve for $\mathrm{CO}_{2}$ emissions: A cointegration analysis for China. Energy Policy, 37, 5170, 2009.

9. ESTEVE V., TAMARIT C. Threshold cointegration and nonlinear adjustment between $\mathrm{CO}_{2}$ and income: The Environmental Kuznets Curve in Spain, 1857-2007. Energy Economics, 34, 2152, 2012.

10. SHAHBAZ M., MUTASCU M., AZIM P. Environmental Kuznets curve in Romania and the role of energy consumption. Renewable and Sustainable Energy Reviews, 18, 169, 2013.

11. AL-MULALI U., WENG-WAI C., SHEAU-TING L., MOHAMMED A.H. Investigating the environmental Kuznets curve (EKC) hypothesis by utilizing the ecological footprint as an indicator of environmental degradation. Ecological Indicators, 48, 319, 2014.

12. APERGIS N., OZTURK I. Testing Environmental Kuznets Curve hypothesis in Asian countries. Ecological Indicators, 52, 18, 2015.

13. CHARFEDDINE L., MRABET Z. The impact of economic development and social-political factors on ecological footprint: A panel data analysis for 15 MENA countries. Renewable and Sustainable Energy Reviews, 76, 147, 2017.

14. LOPEZ R., MITRA S. Corruption, Pollution, and Kuznets Environment Curve. Journal of Environmental Economics and Management, 40, 147, 2000.

15. GALEOTTI M., LANZA A., PAULI F. Reassessing the environmental Kuznets curve for $\mathrm{CO}_{2}$ emissions: A robustness exercise. Ecological Economics, 57, 162, 2006.

16. FRANK J. Is there an "animal welfare Kuznets curve"? Ecological Economics, 66, 489, 2008.

17. YANRONG W., CUILI W., HAN W. Research on the Quantitative Relationship between the Generation of Industrial Solid Waste and per capita GDP of Henan Province. Energy Procedia, 5, 596, 2011. 
18. LI Z., FANG S. Suzhou's Export Trade and Environment: An Empirical Study. Energy Procedia, 5, 2128, 2011.

19. AROURI M. E. H., YOUSSEF A.B., M'HENNI H., RAULT C. Energy consumption, economic growth and $\mathrm{CO}_{2}$ emissions in Middle East and North African countries. Energy Policy, 45, 346, 2012.

20. WONG S.L., CHIA W-M., CHANG Y. Energy consumption and energy R\&D in OECD: Perspectives from oil prices and economic growth. Energy Policy, 62, 1582, 2013.

21. OZTURK I., BILGILI F. Economic growth and biomass consumption nexus: Dynamic panel analysis for SubSahara African countries. Applied Energy, 137, 114, 2014.

22. SAATI S. L., HASSAN M.S., MAHMOOD H., SHAHBAZ M. Coal consumption: An alternate energy resource to fuel economic growth in Pakistan. Economic Modelling, 36, 286, 2014.

23. GUO J., HU Y., XIONG Z., YAN X., REN B., BU R. Spatiotemporal Variations of Growing-season NDVI Associated with Climate Change in Northeastern China's Permafrost Zone. Polish Journal of Environmental Studies, 26, 1527, 2017.

24. FREEMAN S.L., NIEFER M.J., ROOP J.M. Measuring industrial energy intensity: practical issues and problems. Energy Policy, 25 (7), 711, 1997.

25. STREIMIKIENE D. Monitoring of energy supply sustainability in the Baltic Sea region. Energy Policy, 35, 1662, 2007.
26. CHANG M-C. Energy intensity, target level of energy intensity, and room for improvement in energy intensity: An application to the study of regions in the EU. Energy Policy, 67, 652, 2014.

27. ZENG L., XU M., LIANG S., ZENG S., ZHANG T. Revisiting drivers of energy intensity in China during 1997-2007: A structural decomposition analysis. Energy Policy, 67, 6442014.

28. CHANG M-C., YU C-H. Estimation of energy productivity change in Baltic Sea and EU non-Baltic Sea states, Baltic Journal of Economics, 17 (1), 95, 2017.

29. BHATTACHARYA M., RAFIQ S., BHATTACHARYA S. The role of technology on the dynamics of coal consumption-economic growth: New evidence from China. Applied Energy, 154, 693, 2015.

30. CHEN S.Y. The study of energy-saving and emissionabatement, structural adjusting and their impact on the transformation of industrial development model in China. Peking University Press, 2011.

31. SOYTAS U., SARI, R. Energy consumption and GDP: causality relationship in G-7 countries and emerging markets. Energy Economics, 25 (1), 35, 2003.

32. GRANGER C.W.J. Investigating causal relations by econometric models and crossspectral method. Econometrica, 37, 433, 1969. 
